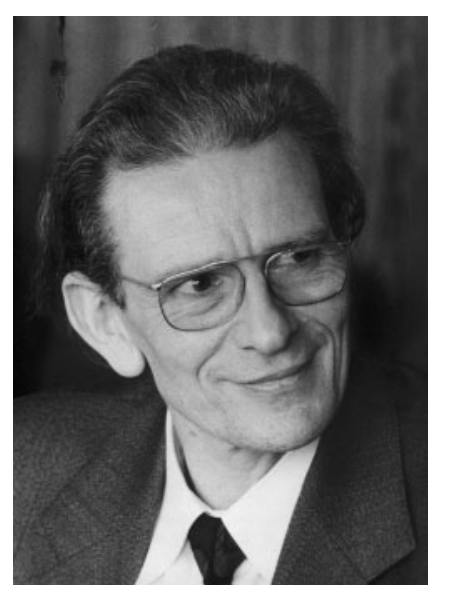

\title{
In memoriam - Norbert Pfennig (1925-2008)
}

Norbert Pfennig, Emeritus Professor of Microbiology at the University of Konstanz, Germany, died on 11 February 2008 at the age of 82 .

Born in 1925, he studied microbiology at the University of Göttingen. In 1952, he received his PhD for a thesis on the formation of actinomycin, in 1957 he became a lecturer and in 1964 associate professor at the same university. Research stays at the universities of Zürich (with T. O. Wikén) and Helsinki (with A. I. Virtanen) and at Rothamstead Station (with N. Walker) supported his early work on actinomycin and on the formation of amino acids by Rhizobium and Streptomyces species. He was especially fascinated by the new paper chromatography techniques then becoming available.

However, his genuine lifelong field of research became the phototrophic bacteria. In 1959, stimulated by H. G. Schlegel, he began to attempt the culture of the phototrophic sulfur bacteria, which at that time had not been obtained in pure culture. Within 2 years, he had developed a new culture technique for these fastidious organisms, which quickly became known worldwide as Pfennig's technique or Pfennig's medium. His further scientific path was decisively set by a sabbatical year with Cornelis B. van Niel at Pacific Grove, California. Pfennig returned to Göttingen with the aim of investigating the physiology and ecology of the bacteria that are involved in the biological sulfur cycle in the sense of van Niel from a holistic viewpoint, which naturally included their systematics. He himself described his motivations thoroughly in his autobiography [Annu Rev Microbiol 47 (1993), 1-31]. He also returned to Göttingen as a new man; he had become an open-minded, merry, stimulating partner, discussing everything. The time in California in the laboratories of van Niel and of Roger Stanier and Germaine Cohen-Bazire in Berkeley, where he was involved in the discovery of the chlorosomes, had made him find his own qualities as microbiologist, researcher and teacher. He brought back with him the open-minded American team spirit and so, in the following years in Göttingen, we brought into pure culture hundreds of strains of purple and green sulfur bacteria (phototrophs) and studied their specific growth requirements with respect to nutrients and light. Norbert Pfennig thus succeeded in isolating almost all phototrophic sulfur bacteria that had been observed in natural environments and described (from nature) since 1832 and in discovering many unknown species. Soon the 'non-sulfur' purple bacteria were added, and there also he discovered new species.

It is therefore not surprising that Pfennig and his co-workers became known worldwide as experts on the taxonomy of phototrophic bacteria and were asked to write the respective chapters in Bergey's Manual, The Prokaryotes, etc. Wellknown scientists came to his lab (amongst others, Ralph Wolfe, Marvin Bryant, Jerald Ensign and Hans van Gemerden) or sent cultures to be identified. Pfennig studied the syntrophisms of the green bacteria and, with Hanno Biebl, discovered the sulfur reducers (Desulfuromonas, etc.); they showed a completely new type of metabolism, coupling the anaerobic reduction of sulfur to the complete oxidation of ethanol or acetate. These organisms were excellently suited to the construction of syntrophic communities with phototrophic bacteria. Several guest professorships followed (in the USA and Turkey, for example). Norbert Pfennig and his doctoral student Friedrich Widdel discovered the enormous breadth of substrate utilization of the sulfatereducing bacteria, thus proving the extraordinary importance of this metabolic group in nature, something that had long been postulated previously. Many of his publications were of relevance to systematics and so it is not surprising that the Board of Trustees of the Bergey's Manual Trust elected Norbert Pfennig as a member in 1974 where, for many years, he influenced the development of bacterial systematics.

After he had declined several offers of full professorships of other universities, Pfennig accepted an associate professorship at the University of Konstanz which, a year later, was 
turned into a full professorship of limnology and microbiology of lakes and rivers. With the large lake Bodensee (Lake Constance) outdoors, he could follow his affection for the bacteria of water bodies. Friedrich Widdel, Bernhard Schink and Heribert Cypionka formed the ideal team with Norbert Pfennig to tackle the anaerobic sediment bacteria of Lake Constance. Many projects were also started together with Swiss colleagues. So he succeeded for the first time to cultivate in pure culture anaerobic ciliates with methanogenic archaea as endosymbionts. Together with Jörg Overmann, Pfennig isolated a Chlorobium phaeobacteroides strain from the depths of the Black Sea that lives at the lowest light intensity found so far to support life.

Norbert Pfennig's scientific merits were honoured many times: in 1980 he received the research prize of the German DGHM, in 1982 the Academy of Sciences at Göttingen elected him as a member, he received honorary memberships of the British SGM and the German VAAM, in 1992 the Bergey's Manual Trust honoured him with the Bergey Medal and also in 1992 he received an honorary doctorate of the science faculty of the University of Bonn. After he retired on 1 October 1990, he continued to keep in close contact with colleagues and former students, and many remain thankful to him for his profound and helpful discussions.

Quite a number of his former students and co-workers are now professors and pass on his views and insights to their students. I speak for many colleagues, I believe, when I say that we have lost a friend and that microbiology has lost a unique and wonderful scientist and teacher. Norbert Pfennig leaves his wife Helga, five children and nine grandchildren. We offer our condolences and mourn with them.

Hans G. Trüper, Institut für Mikrobiologie \& Biotechnologie, Universität Bonn. 